\section{Gender, gestation and ectogenesis: self- determination for pregnant people ahead of artificial wombs}

\author{
Claire Horn
}

\begin{abstract}
In this short response, I agree with Cavaliere's recent invitation to consider ectogenesis, the process of gestation occurring outside the body, as a political perspective and provocation to building a world in which reproductive and care labour are more justly distributed. But I argue that much of the literature Cavaliere addresses in which scholars argue that artificial wombs may produce greater gender equality has the limitation of taking a fixed, binary and biological approach to sex and gender. I argue that in taking steps toward the possibility of more just practices of caregiving and family making, we must look first not to artificial womb technologies but to addressing the ways that contemporary legal and social practices that enforce essentialising, binary ways of thinking about reproductive bodies inhibit this goal.
\end{abstract}

In her recent article, Cavaliere persuasively intervenes in a growing body of literature in which scholars have suggested that artificial womb technologies might serve to alleviate gender inequality. As Cavaliere argues, these kinds of claims might most usefully be framed as political provocations, invitations to attend to the way in which 'the sets of arrangements that enable a society to reproduce itself, such as domestic labour, pregnancies, and childrearing, are currently largely borne by women'. ${ }^{i}$ We do not yet know to what extent artificial womb technologies will ever be capable of replicating gestation. In forthcoming work with Romanis, I consider the scientific barriers that might draw speculation on full ectogenesis into question and outline some of the existing legal realities that limit the possibility that ectogenesis could have the radical impact of which some feminist scholars have dreamt. ${ }^{\text {ii }}$ Cavaliere's assertion that the

${ }^{i}$ Cavaliere G. Gestation, equality, and freedom: ectogenesis as a political perspective. J Med Ethics 2020; 46, 76-82.

Department of Law, Birkbeck University of London, London, UK

Correspondence to Claire Horn, Law, Birkbeck University of London, London WC1E 6HE, UK; chorn04@mail.bbk.ac.uk possibility that ectogenesis may one day be able to redistribute the physical act of gestation but will do nothing on its own to address the stark realities of contemporary social inequality is one with which I wholeheartedly agree.

I want to offer here, however, a brief reflection on the understanding of gender in Cavaliere's article as well as many of the articles her work is in conversation with. As Cavaliere eloquently demonstrates, several feminist scholars have made some version of the claim that ectogenesis could help further the cause of gender equality by allowing women to share the work of gestating with men. While Cavaliere's work is dedicated to responding to these authors, it bears noting here that there is also a body of bioethical literature in which scholars make the related claim that artificial wombs might increase the rights and responsibilities of male progenitors towards the fetus. These claims importantly diverge from those made in the feminist texts Cavaliere discusses: they are not focused on the possibility of ectogenesis to alleviate the weight of reproductive and care labour on women, but rather on the possibility that ectogenesis might allow men greater access to a gestating fetus. While scholars writing in this second group sometimes share the aim of feminists who seek to promote a greater balance in gendered reproductive labour, at other times, they are implying that reproductive autonomy for women has gone too far and that women have been granted a 'monopoly [...in] deciding the fate of the embryo and foetus'. iii Welin neglects to acknowledge that there are in fact vitally important reasons why we might seek to give a pregnant person sole charge over a fetus gestating in their body (namely, to prevent the serious infringement on their

ii $* * *$ and Romanis E.C. Establishing Boundaries for Speculation About Artificial Wombs, In Thomson M, Dietz C, and Travis M, eds, A Jurisprudence of the Body. UK: Palgrave 2020 (in press).

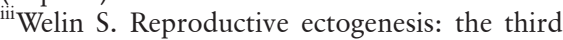
era of human reproduction and some moral consequences. Science and Engineering Ethics 2004 10;4, 615-626. Ectogenesis, Gender, and the Gestating Body. bodily autonomy that would occur should another progenitor be allowed to intervene). As I argue elsewhere, the fight for protecting pregnant people's reproductive autonomy in the form of global protection for abortion rights and access to reproductive care throughout the lifespan is very much ongoing. .v $^{\text {. }}$

But despite differing political aims, both the feminist literature analysed by Cavaliere and the bioethical literature I have noted above arrive at the same place: the claim that artificial wombs could radically alter the relationship between men, women and fetuses. What allows these two discourses to converge in a claim that artificial wombs may produce 'gender equality' is a shared treatment of 'gender' and 'sex' as interchangeable, binary and fixed. According to this literature, ectogenesis produces equality in gestation, and revolutionises the very act of gestating, by negating the purported biological reality that only women can gestate and allowing this process to be shared with or redistributed to men. As Cavaliere writes, the conclusion drawn in much of this scholarship is that the technology will create a new kind of gender equality, and in some instances, that ectogenesis should be pursued precisely because it could liberate women 'from the tyranny of biology'.

I support Cavaliere's call for ectogenesis as political provocation and indeed imagining ectogenesis as a means of sharing care labour might do much to draw attention to its contemporary unequal distribution. But there is another political provocation that I believe we should attend to here. I agree with Cavaliere, and the feminist authors with whom she engages, that the social and physical ways in which pregnancy has long impacted women's bodies in particular is a site of urgency. I agree also that balancing the unequal distribution of reproductive labour within cisgendered heterosexual couples would be a significant site of social progress. But in speculating on the future impact of ectogenesis on gender inequality, I think our conversations will be most generative if we begin the project of disentangling gender from reproduction by rejecting binary understandings of human reproductive roles.

iv $* * *$ Ectogenesis is for feminists: Reclaiming Artificial Wombs from Antiabortion Discourse. Catalyst: Feminism, Theory, Technoscience 2020 (in press).

${ }^{\mathrm{v}}$ Firestone $\mathrm{S}$. The dialectic of sex: the case for feminist revolution. 2nd Edition. London, UK: Verso, 2015. http://liveunitedblog.org/the-dialectic-of-sex-the-case-for-feministrevolution-ebook-good-reads-shulamith-firestone.pdf 
The texts that Cavaliere addresses in her article as well as the bioethical texts that argue ectogenesis could offer more reproductive autonomy to male progenitors, take sex and gender as binary, fixed categories in order to read artificial wombs as the place at which gender equality can begin. But while it is true that in moving gestation outside of the body, artificial wombs open 'new possibilities that could upset the traditional male-dominated family structure', ${ }^{\mathrm{vi}}$ many families, and many pregnant people, have long disrupted these norms. Legal regulation, healthcare provisions and existing social norms at best lag behind in protecting these families, and at worst, place obstacles in their paths. Consider, for instance, the refusal of a trans man's self-determination inherent in the recent UK high court ruling in which a judge held that the man could not be registered as the 'parent' or the 'father' of his child but must be a 'male mother'. ${ }^{\text {ii }}$ While, as Pearce et $a l^{\text {viii }}$ have commented, this ruling has compelling implications for the 'legal undoing of binary understandings of reproduction and gender, sex and the body', it also speaks to the contemporary

${ }^{v i}$ Singer P, Ectogenesis WD. Ectogenesis. In: Gelfand S, Shook JR, eds. Artificial womb technology and the future of human reproduction. Amsterdam, NL: Rodopi, 2006: 9-25.

vii I discuss this further with Romanis in forthcoming work, see N2

viii Pearce R, Hines S, Pfeffer C, Riggs DW, Ruspini E, White FR. Of trans fathers and male mothers - the importance of centering experience. Available: https:// transpregnancy.leeds.ac.uk/2019/09/26/ of-trans-fathers-and-male-mothers-the-importance-of-centering-experience/ [Accessed 18 Feb 2020] limitations of legal practices in recognising that not everyone who gestates is a woman or a mother. In creating a world in which ectogenesis could actually be used in the service of justice, and in the service of redistributing or sharing the work of gestation, thenwe need to first acknowledge that pregnancy is not 'something that can only affect women' ${ }^{\text {,ix }}$ and we need to arrive at a social circumstance in which the pregnancies of people of many sexes and genders are accepted on their own terms.

If we regard redistributing the association of gestation with women alone as a desirable goal (as I do), we would do well to first address the ways that contemporary legal and social practices that enforce essentialising, binary ways of thinking about reproductive bodies inhibit this goal. When it comes to sex and gender, biology is a 'tyranny' that we can refuse. I share Cavaliere's desire for a world that is more equal and more just, one in which we might reach for the feminist utopia on which Firestone speculated. Seeking 'a true redistribution of the burdens and responsibilities of social reproduction' might also begin with rejecting a biologically rendered definition of gender and acknowledging that we already live in a world in which men, non-binary and genderqueer people give birth and in which many women cannot or do not gestate. ${ }^{\mathrm{x}}$ To achieve the 'comprehensive and radical programme for (feminist) revolution, leading to the elimination of (sexual) classes', we might set our sights beyond gender 'equality' between men

${ }^{\text {ix }}$ Ibid

${ }^{\mathrm{x}} \mathrm{N} 1,18$ and women and towards justice for pregnant people and families of all genders. ${ }^{\mathrm{xi}}$

Acknowledgements The author acknowledges the funding of the Wellcome Trust.

Contributors I am the sole contributor to this work. Funding This study was funded by Wellcome Trust. Competing interests None declared.

Patient consent for publication Not required.

Provenance and peer review Not commissioned; internally peer reviewed.

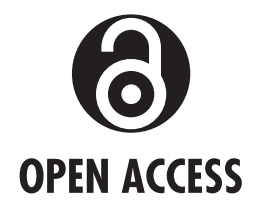

Open access This is an open access article distributed in accordance with the Creative Commons Attribution Non Commercial (CC BY-NC 4.0) license, which permits others to distribute, remix, adapt, build upon this work non-commercially, and license their derivative works on different terms, provided the original work is properly cited, appropriate credit is given, any changes made indicated, and the use is non-commercial. See: http:// creativecommons.org/licenses/by-nc/4.0/.

(C) Author(s) (or their employer(s)) 2020. Re-use permitted under CC BY-NC. No commercial re-use. See rights and permissions. Published by BMJ.

\section{Check for updates}

To cite Horn C. J Med Ethics 2020;46:787-788.

Received 19 February 2020

Accepted 27 March 2020

Published Online First 4 May 2020

J Med Ethics 2020:46:787-788.

doi:10.1136/medethics-2020-106156

ORCID iD

Claire Horn http://orcid.org/0000-0002-3212-2577

${ }^{x i}$ Ibid, 16 